\title{
Raamat identiteedimärkidest
}

\author{
Piret Viires $^{\mathrm{a}}$ \\ ${ }^{a}$ Tallinna Ülikooli humanitaarteaduste instituut
}

\begin{abstract}
Ehala, M. (2018). Identideedimärgid. Ühtekuuluvuse anatoomia. Tallinn: Künnimees.
\end{abstract}

Martin Ehala monograafia „Identiteedimärgid. Ühtekuuluvuse anatoomia“ ilmus kõigepealt inglise keeles Routledge'i kirjastuses $(2017,2018)$ ja seejärel, 2018. aastal ka eestikeelse tõlkena. Oma identiteediteooria väljatöötamise eest pälvis Ehala 2018. aastal riikliku teaduspreemia humanitaarteaduste alal.

Raamatu ilmumine mainekas Routledge'i teaduskirjastuses ja teaduspreemiaga tunnustamine näitavad, et Martin Ehala uurimus identiteedimärkidest on pälvinud tähelepanu nii rahvusvaheliselt kui ka meil Eestis. Milles siis seisneb Martin Ehala identiteedikäsitluse tuum? Miks on see käsitlus originaalne ja huvipakkuv?

Raamatu kirjutamise põhjusena märgib Ehala, et identiteet on teema, mis on kujunenud peamiseks ühiskondlike pingete allikaks, ja identiteediküsimused on üle maailma üha probleemsemad. Samas on üldine arusaam identiteedi olemusest hägune, kuna mõistel on eri valdkondades erinevad tähendused, pealegi on mõned teadlased identiteedi mõistest kui ebamäärasest üldse loobunud. Martin Ehala püüab sellesse segadusse süsteemi tuua, luues üldistava ja eri teadusvaldkondi ühendava identiteediteooria. Eeskujuks on Ehalale keeleteadus, kuna keel on nähtusena sama keeruline kui identiteet, kuid tema identiteediteooria aluse moodustab semiootika - märk. Siit tulenevad Ehala kaks põhieesmärki - tutvustada kollektiivse identiteedi põhitahke ja esitada algupärane teooria identiteedi olemuse kohta, võttes aluseks märgi mõiste -, nagu seda on ka raamatus rõhutatud.

Raamatu põhiväide ongi, et identiteet on märk, nagu seda mõistetakse semiootikas ja keeleteaduses. Sõnad on sümboli tüüpi märgid, kus signaali ja tähenduse seos on sageli meelevaldne ja kokkuleppeline. Toetudes John Searle'ile, kelle meelest toimivad kõik sotsiaalsed institutsioonid samuti sümbolitena nagu sõnad, leiab Ehala, et see laieneb ka identiteedile - signaali ja tähenduse seos on kokkuleppeline. Ehala väidab, et inimesed mõistavad teiste identiteete samamoodi, nagu nad aduvad keeleliselt väljendatut. Seega 
on Ehala arvates identiteedimärgid nagu sõnad - neil on kaks poolt: signaal ja tähendus. Ehala kirjutab: „Inimene edastab oma käitumise ja olekuga identiteedisignaale umbes nagu ta kõneleks ning neid signaale lugedes teevad teised inimesed järeldusi tema tõekspidamiste, suhtumise ja tõenäolise käitumise kohta, st tema identiteedi kohta" (lk 16).

Ehala leiab, et nagu sõnadelgi, on ka identiteedisignaalidel oma tähendused. Tähenduste keskmes on tuumväärtused ehk teadmine, mida selle identiteediga inimene võiks mõelda ja uskuda. Nende tuumväärtuste põhjal saavad kujuneda hinnangud ühe või teise identiteedi kohta.

Kuna identiteet toimib Ehala meelest ühiskonnas samamoodi kui keel, siis kõik identiteedimärgid koos nendevahelisi suhteid reguleerivate reeglitega moodustavad omakorda n-ö identiteedigrammatika, mis on konkreetse ühiskonna sotsiaalse süsteemi plaan. Ehala leiab, et see grammatika määrab valitseva väärtussüsteemi alusel eri identiteetide staatuse ja omavahelised võimusuhted. Kuigi identiteet ei ole inimese olemus, vaid midagi, mis inimesel on, siis vaidlustab Ehala väite, et inimene ise määrab oma identiteedi ja teised peavad seda aktsepteerima. Identiteet toimib keerulisemalt.

Raamatu oluline osa on pühendatud rahvuslikule ja kollektiivsele identiteedile. Küsitakse, mis paneb inimesed uskuma, et nad on üks rahvus, ja mis tingimustel nad suudavad tegutseda kollektiivse üksusena. Ehala väidab, et kõige tähtsam on inimeste emotsionaalne side oma identiteedimärgiga, pühendumus abstraktsele ideele, sotsiaalsele representatsioonile. Ehala eristab siin külma ja kuuma rühma, vastavalt sellele, kas emotsionaalne side oma identiteedimärgiga on ükskõikne või kirglik. Nende kahe rühma kokkupuude tänapäeva maailmas on paratamatu ja nende kontaktide tagajärgi on Ehala arvates võimalik lihtsamini mõista ja ennustada, kui tuntakse ühtekuuluvuse anatoomiat.

Ehala toob esile, et identiteediloomel on kaks laiemat eesmärki: vormida elujõulised kollektiivsed identiteedid ja kujundada nende identiteetide omanike seotus kollektiivse identiteediga. Seejuures on tähtis pöörata tähelepanu kollektiivsetele emotsioonidele, sest need aitavad kujundada ühtekuuluvust. Ehala rõhutab, et kollektiivsete emotsioonide tähtsust ei tasu alahinnata - nendega arvestamine oleks aidanud pääseda nii mõnestki poliitilisest valearvestusest.

Raamatu lõpetab „Epiloog“', mis on pühendatud tänapäeva muutuvale maailmale ja kollektiivse identiteedi rollile selles. Ehala näeb läänelikus liberaalses multikulturalismis paradoksi, kuna liberaalse multikulturalismi puhul kaotab rahvus ühiskonnas oma funktsiooni eri kogukondi ühendava identiteedina. Nii kaob ühiskonnas sidusus ja on oht killustuda eri identiteediga rühmadeks. Prognoos, mida Ehala pakub ühiskonna sidususe tagamiseks, on kas tugev totaalset järelevalvet tegev riik või oht, et mõni ühiskonnarühm kuumeneb ja 
hakkab teisi alla suruma. Need prognoosid on muidugi oletuslikud, kuid samas mõtlemapanevad ja hoiatavad.

Ehala esitab raamatu lõpus hulga küsimusi, mis on seotud ühelt poolt mobiilsuse, immigratsiooni ja virtuaalkogukondadega, teiselt poolt aga ka äärmusindividualismi domineerimise võimalikkusega. Raamat lõppeb õigustatud tõdemusega, et vastused neile paljudele olulistele küsimustele selguvad alles kaugemas tulevikus.

Martin Ehala raamatu tähtsus seisneb identiteediproblemaatika toomises teadusliku arutluse keskmesse, omaette tervikliku ja süsteemse identiteediteooria loomises ning ka kollektiivse identiteedi emotsionaalse külje rõhutamises. Ehala raamat aitab mõelda identiteedi teemade üle täpsemas raamistikus ja märgata kollektiivse identiteedi avaldumise vorme ja ühtekuuluvuse emotsionaalseid tahke väga erinevates valdkondades - laiemalt nii poliitikas kui ka argielus või kitsamalt ühiskondlikes institutsioonides (sh haridusasutused). Sellisena on see raamat oluline ja soovitatav teos kõigile, keda huvitavad identiteediküsimused ja ühiskonna toimimise mehhanismid. 